\title{
Detection of Plantago asiatica mosaic virus in lily hybrid plants (Lilium spp.) in Costa Rica grown from imported bulbs
}

\author{
Mauricio Montero-Astúa ${ }^{1,2}$ (D) Laura Garita $^{1} \cdot$ Elena Vásquez $^{1} \cdot$ John Hammond $^{3}$. \\ Lisela Moreira $^{1,2}$
}

Received: 21 August 2017 / Accepted: 9 November 2017 / Published online: 17 November 2017

(C) Australasian Plant Pathology Society Inc. 2017

\begin{abstract}
Plantago asiatica mosaic virus (P1AMV) was detected in Costa Rica infecting lily plants showing foliar chlorotic and necrotic streaking. Virus identity was established by TEM, sequencing and ELISA. Pathogenicity was confirmed on Nicotiana benthamiana by mechanical inoculation, and PlAMV was detected by ELISA and RT-PCR.
\end{abstract}

Keywords Potexvirus · ELISA · RT-PCR · PlAMV · International trade of infected plants $\cdot$ Emerging viral disease

Plantago asiatica mosaic virus (PlAMV) (genus Potexvirus; family Alphaflexiviridae; order Tymovirales) infects lily plants (Lilium spp.) among other hosts (Komatsu et al. 2017). PlAMV was initially described from Plantago asiatica in Russia (Kostin and Volkov 1976, in: Solovyev et al. 1994). Currently, PlAMV is distributed in several countries in Asia, Europe and the Americas, including Chile (Vidal et al. 2016), China (Xu et al. 2017), Hungary (Pájtli et al. 2015), Italy (Parrella et al. 2015), Japan (Ozeki et al. 2006), Korea (Lim et al. 2016), and the USA (Hammond et al. 2015), and causing up to $80 \%$ losses in The Netherlands (Anonymous 2010). In addition, a virus infecting heavenly bamboo (Nandina domestica) in California, named Nandina mosaic virus

Mauricio Montero-Astúa

mauricio.monteroastua@ucr.ac.cr

1 Centro de Investigación en Biología Celular y Molecular (CIBCM), Universidad de Costa Rica (UCR), San José 11501-2060, Costa Rica

2 Escuela de Agronomía, UCR, San José 11501-2060, Costa Rica

3 Floral and Nursery Plants Research Unit, USDA-ARS, USNA, Beltsville, MD 20705, USA
(Zettler et al. 1980), is now recognized as a strain of PlAMV (Hughes et al. 2005).

Reports suggest that PlAMV is disseminated internationally by trading of infected bulbs (Hammond et al. 2015; Pájtli et al. 2015; Parrella et al. 2015). Moreover, PlAMV is mechanically transmitted (by sap) and no arthropod vector is known. The virus naturally infects hosts belonging to diverse plant families including Plantaginaceae (plantago), Liliaceae (lily), Primulaceae (primrose), Violaceae (violet), Scrophulariaceae (Chinese foxglove), and Berberidaceae (nandina) (Kostin and Volkov 1976, in: Solovyev et al. 1994; Komatsu et al. 2008, 2017; Kwon et al. 2017); and experimental hosts from additional plant families (Kostin and Volkov 1976; J. Hammond, unpublished).

During a survey to detect viruses belonging to the genus Orthotospovirus (family Tospoviridae; order Bunyavirales) (Adams et al. 2017) in Costa Rica, two Asiatic lily hybrid plants were collected at a greenhouse in Cartago Province on June 2013 (samples T188 and T189). The symptoms included brown necrotic streaking and irregular leaf chlorosis (Fig. 1a, b). RNA was extracted (RNeasy Plant Mini Kit, Qiagen, Germany) and cDNA was obtained by retrotranscription (Maxima $\mathrm{H}$ Minus First Strand cDNA Synthesis Kit, Thermo Scientific, Lithuania) primed with random hexamers. cDNAs were tested by PCR (DreamTaq PCR Master Mix, Thermo Scientific, Lithuania) with five different primer pairs for orthotospovirus detection (Eiras et al. 2001; Uga and Tsuda 2005). An amplicon under 500 bp was obtained for both plants, T188 and T189, using primer pair IYSV837 / Tos-R15 (Uga and Tsuda 2005) and sequenced (Macrogen, Korea) in both directions. The resulting sequences (T188, KY807780; T189, KY807781) had top BLAST hits in GenBank (National Center for Biotechnology Information, USA) to isolates of PlAMV. The unexpected amplification of PlAMV sequence using primers designed to detect 
Fig. 1 Detection and pathogenicity of Plantago asiatica mosaic virus (PlAMV) in Costa Rica. Symptoms of PIAMV observed on a Lilium sp. plant (T188) (a, b). Transmission electron microscopy (TEM) image from sample T188 leaf tissue with several flexuous rods in the cytoplasm of a cell (c); scale bar represent $500 \mathrm{~nm}$. Symptoms observed on Nicotiana benthamiana after mechanical inoculation with sample T189, 22 days after inoculation (dai) (d), with sample T188, 36 dai (e), and buffer-inoculated plant, 22 dai (f)
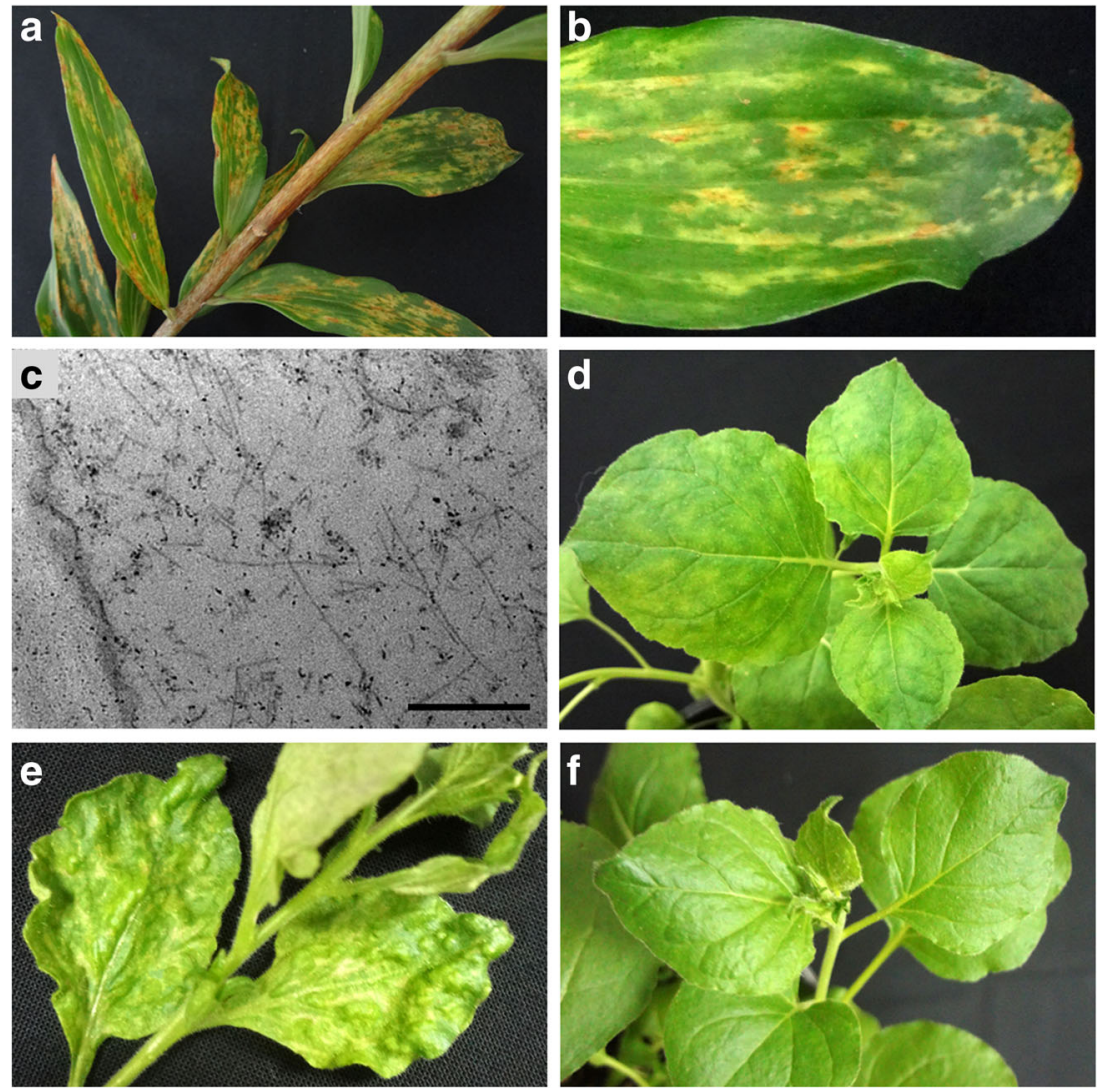

tospoviruses was investigated by aligning the sequences of primers IYSV-837 and Tos-R15 against the PIAMV genome. All alignments identified included multiple mismatches, particularly with primer Tos-R15, which has five two-fold degenerate positions near the $3^{\prime}$ end, and potential to prime on both strands of the PlAMV genome. The initial detection of

Table 1 Plantago asiatica mosaic virus (PIAMV) detection ${ }^{\mathrm{a}}$ in lily samples in Costa Rica

\begin{tabular}{|c|c|c|c|}
\hline \multirow[t]{2}{*}{ Sample } & \multirow[t]{2}{*}{ DAS-ELISA $^{\mathrm{b}}$} & \multicolumn{2}{|c|}{$\begin{array}{l}\text { Amplification by RT-PCR } \\
\text { (GenBank accession numbers for obtained sequences) }\end{array}$} \\
\hline & & Potex 4 / Potex 5 (Potexvirus) & CP-F2 / CP-R3 (PlAMV) \\
\hline Greenhouse lily, T188 & + & $+(\mathrm{KY} 807782)$ & $+(\mathrm{KY} 807776)$ \\
\hline Greenhouse lily, T189 & + & $+(\mathrm{KY} 807784)$ & $+(\mathrm{KY} 807777)$ \\
\hline N. benthamiana inoculated with $\mathrm{T} 188$ & + & $+(\mathrm{KY} 807783)$ & $++^{f}$ \\
\hline N. benthamiana inoculated with $\mathrm{T} 189$ & + & $+(\mathrm{KY} 807785)$ & $+(\mathrm{KY} 807778)$ \\
\hline Supermarket lily, $\mathrm{L}^{\mathrm{d}}$ & $\mathrm{Nt}$ & - & - \\
\hline Supermarket lily, L2 ${ }^{\mathrm{d}}$ & $\mathrm{Nt}$ & - & - \\
\hline Supermarket lily, L3 ${ }^{\mathrm{d}}$ & $\mathrm{Nt}$ & $+(\mathrm{KY} 807786)$ & $+(\mathrm{KY} 807779)$ \\
\hline Supermarket lily, $\mathrm{L}^{\mathrm{d}}$ & $\mathrm{Nt}$ & - & - \\
\hline Potexvirus positive control $(\mathrm{CymMV})^{\mathrm{e}}$ & $\mathrm{Nt}$ & $+(\mathrm{KY} 807788)$ & - \\
\hline
\end{tabular}

${ }^{\text {a }}$ Positive result (+), negative result (-), or not tested $(\mathrm{Nt})$

${ }^{\mathrm{b}}$ Double antibody sandwich ELISA for the detection of Nandina mosaic virus, an isolate of the virus PIAMV

${ }^{\mathrm{c}}$ Primer pairs used herein for the detection of virus isolates belonging to: $i$. the viral genus Potexvirus, Potex4/Potex5 (Miglino et al. 2006), and ii. the species Plantago asiatica mosaic virus, CP-F2/CP-R3 (Hammond et al. 2015)

${ }^{\mathrm{d}}$ Asymptomatic plants

${ }^{\mathrm{e}}$ Cymbidium mosaic virus (CymMV) infecting Phaius tankervilliae (Moreira et al. 1998)

${ }^{\mathrm{f}}$ No final contig. Sequencing reaction with forward primer resulted in PIAMV sequence; however, the reaction with reverse primer failed 
PlAMV using 'tospovirus-specific' primers was verified by testing with primer pairs for general potexvirus detection (Potex $4 /$ Potex 5, Miglino et al. 2006) and for specific detection of PlAMV (PlAMV CP-F2 / CP-R3, Hammond et al. 2015). As negative controls, four symptomless lily plants (two pots, 2 plants per pot) were purchased at a supermarket in San José Province. RNA was extracted from each plant (L1 to L4) and processed as previously described. As a positive control for potexvirus detection, RNA was extracted from a Phaius tankervilliae plant infected with Cymbidium mosaic virus (CymMV) (genus Potexvirus) (Moreira et al. 1998). The two greenhouse lily plants (T188 and T189) and one of the supermarket (symptomless) plants (L3) yielded positive results with both generic potexvirus, and PlAMV-specific, primer pairs (Table 1).

Table 2 Pairwise nucleotide comparisons ${ }^{\mathrm{a}}$ (estimates of evolutionary divergence between sequences) for 24 Plantago asiatica mosaic virus isolates and one isolate each of tulip virus $\mathrm{x}$ and Cymbidium mosaic virus

\begin{tabular}{|c|c|c|c|c|c|c|c|c|c|c|c|c|c|c|c|}
\hline & Part A. Virus isolates & 1 & 2 & 3 & 4 & 5 & 6 & 7 & 8 & 9 & 10 & 11 & 12 & 13 & 14 \\
\hline 1 & KY807782_PIAMV_(T188)_CRI & & 0.003 & 0.003 & 0.004 & 0.016 & 0.004 & 0.016 & 0.014 & 0.014 & 0.014 & 0.015 & 0.014 & 0.014 & 0.013 \\
\hline 2 & KY807784_PIAMV_(T189)_CRI & 0.007 & & 0.002 & 0.004 & 0.016 & 0.004 & 0.016 & 0.014 & 0.014 & 0.014 & 0.015 & 0.014 & 0.014 & 0.013 \\
\hline 3 & KY807786_PIAMV_(L3)_CRI & 0.007 & 0.003 & & 0.004 & 0.016 & 0.004 & 0.016 & 0.014 & 0.014 & 0.014 & 0.015 & 0.014 & 0.015 & 0.013 \\
\hline 4 & KF471012_PIAMV_(Sorbonne)_NED & 0.012 & 0.012 & 0.012 & & 0.016 & 0.003 & 0.016 & 0.014 & 0.014 & 0.014 & 0.014 & 0.014 & 0.014 & 0.013 \\
\hline 5 & NC003849_PIAMV_RUS & 0.169 & 0.168 & 0.168 & 0.174 & & 0.016 & 0.015 & 0.016 & 0.016 & 0.016 & 0.016 & 0.016 & 0.016 & 0.016 \\
\hline 6 & LN794199_PIAMV_(Concador)_HUN & 0.010 & 0.010 & 0.010 & 0.005 & 0.169 & & 0.016 & 0.014 & 0.014 & 0.014 & 0.014 & 0.014 & 0.014 & 0.013 \\
\hline 7 & AY800279_NaMV_(PLH1)_USA & 0.183 & 0.178 & 0.178 & 0.183 & 0.164 & 0.183 & & 0.016 & 0.016 & 0.016 & 0.016 & 0.016 & 0.016 & 0.016 \\
\hline 8 & AB360790_PIAMV_(Li1)_JPN & 0.141 & 0.141 & 0.141 & 0.142 & 0.176 & 0.139 & 0.183 & & 0.000 & 0.000 & 0.003 & 0.002 & 0.003 & 0.011 \\
\hline 9 & AB360791_PIAMV_(Li2)_JPN & 0.141 & 0.141 & 0.141 & 0.142 & 0.176 & 0.139 & 0.183 & 0.000 & & 0.000 & 0.003 & 0.002 & 0.003 & 0.011 \\
\hline 10 & AB360792_PIAMV_(Li3)_JPN & 0.141 & 0.141 & 0.141 & 0.142 & 0.176 & 0.139 & 0.183 & 0.000 & 0.000 & & 0.003 & 0.002 & 0.003 & 0.011 \\
\hline 11 & AB360793_PIAMV_(Li4)_JPN & 0.142 & 0.142 & 0.142 & 0.144 & 0.178 & 0.141 & 0.184 & 0.005 & 0.005 & 0.005 & & 0.002 & 0.003 & 0.011 \\
\hline 12 & AB360794_PIAMV_(Li5)_JPN & 0.139 & 0.139 & 0.139 & 0.141 & 0.174 & 0.137 & 0.181 & 0.002 & 0.002 & 0.002 & 0.003 & & 0,003 & 0,011 \\
\hline 13 & AB360795_PIAMV_(Li6)_JPN & 0.142 & 0.142 & 0.142 & 0.144 & 0.174 & 0.141 & 0.183 & 0.007 & 0.007 & 0.007 & 0.008 & 0.005 & & 0.011 \\
\hline 14 & AB360796_PIAMV_(Pr)_JPN & 0.127 & 0.126 & 0.129 & 0.127 & 0.179 & 0.124 & 0.198 & 0.079 & 0.079 & 0.079 & 0.080 & 0.077 & 0.082 & \\
\hline 15 & LC155796_PIAMV_(Vi)_JPN & 0.204 & 0.206 & 0.206 & 0.203 & 0.206 & 0.199 & 0.214 & 0.194 & 0.194 & 0.194 & 0.196 & 0.193 & 0.193 & 0.211 \\
\hline 16 & LC155795_PIAMV_(NJ)_JPN & 0.198 & 0.194 & 0.194 & 0.199 & 0.181 & 0.199 & 0.184 & 0.198 & 0.198 & 0.198 & 0.199 & 0.196 & 0.198 & 0.219 \\
\hline 17 & KX245539_PIAMV_(CAAS01)_CHN & 0.010 & 0.010 & 0.010 & 0.005 & 0.171 & 0.003 & 0.179 & 0.139 & 0.139 & 0.139 & 0.141 & 0.137 & 0.141 & 0.124 \\
\hline 18 & KU159093_PIAMV_(Ko-YS)_KOR & 0.012 & 0.012 & 0.012 & 0.007 & 0.174 & 0.005 & 0.184 & 0.141 & 0.141 & 0.141 & 0.142 & 0.139 & 0.142 & 0.126 \\
\hline 19 & KU159089_PIAMV_(Ko-JJ_2-1)_KOR & 0.008 & 0.008 & 0.008 & 0.003 & 0.171 & 0.002 & 0.181 & 0.141 & 0.141 & 0.141 & 0.142 & 0.139 & 0.142 & 0.126 \\
\hline 20 & KU159091_PIAMV_(Ko-JJ_2-2)_KOR & 0.008 & 0.008 & 0.008 & 0.003 & 0.171 & 0.002 & 0.181 & 0.141 & 0.141 & 0.141 & 0.142 & 0.139 & 0.142 & 0.126 \\
\hline 21 & KU159090_PIAMV_(Ko-JJ_2-4)_KOR & 0.008 & 0.008 & 0.008 & 0.003 & 0.171 & 0.002 & 0.181 & 0.141 & 0.141 & 0.141 & 0.142 & 0.139 & 0.142 & 0.126 \\
\hline 22 & KU159092_PIAMV_(Ko-JJ_3-1)_KOR & 0.010 & 0.010 & 0.010 & 0.005 & 0.171 & 0.003 & 0.183 & 0.139 & 0.139 & 0.139 & 0.141 & 0.137 & 0.141 & 0.124 \\
\hline 23 & KU697313_PIAMV_(Gunwi)_KOR & 0.162 & 0.156 & 0.159 & 0.164 & 0.127 & 0.161 & 0.191 & 0.173 & 0.173 & 0.173 & 0.174 & 0.171 & 0.173 & 0.176 \\
\hline 24 & KT717325_PIAMV_(kr)_KOR & 0.010 & 0.010 & 0.010 & 0.005 & 0.173 & 0.003 & 0.183 & 0.141 & 0.141 & 0.141 & 0.142 & 0.139 & 0.142 & 0.126 \\
\hline 25 & AB066288_TVX_JPN & 0.228 & 0.228 & 0.228 & 0.231 & 0.238 & 0.229 & 0.261 & 0.245 & 0.245 & 0.245 & 0.246 & 0.243 & 0.245 & 0.255 \\
\hline 26 & NC001812_CymMV_SGP & 0.400 & 0.400 & 0.397 & 0.402 & 0.382 & 0.399 & 0.387 & 0.410 & 0.410 & 0.410 & 0.412 & 0.409 & 0.407 & 0.399 \\
\hline
\end{tabular}

\begin{tabular}{|c|c|c|c|c|c|c|c|c|c|c|c|c|c|}
\hline & Part B. Virus isolates & 15 & 16 & 17 & 18 & 19 & 20 & 21 & 22 & 23 & 24 & 25 & 26 \\
\hline 1 & KY807782_PIAMV_(T188)_CRI & 0.016 & 0.016 & 0.004 & 0.004 & 0.004 & 0.004 & 0.004 & 0.004 & 0.016 & 0.004 & 0.017 & 0.020 \\
\hline 2 & KY807784_PIAMV_(T189)_CRI & 0.016 & 0.016 & 0.004 & 0.004 & 0.004 & 0.004 & 0.004 & 0.004 & 0.015 & 0.004 & 0.017 & 0.020 \\
\hline 3 & KY807786_PIAMV_(L3)_CRI & 0.016 & 0.016 & 0.004 & 0.004 & 0.004 & 0.004 & 0.004 & 0.004 & 0.016 & 0.004 & 0.017 & 0.020 \\
\hline 4 & KF471012_PIAMV_(Sorbonne)_NED & 0.016 & 0.016 & 0.003 & 0.003 & 0.002 & 0.002 & 0.002 & 0.003 & 0.016 & 0.003 & 0.017 & 0.020 \\
\hline 5 & NC003849_PIAMV_RUS & 0.016 & 0.016 & 0.016 & 0.016 & 0.016 & 0.016 & 0.016 & 0.016 & 0.013 & 0.016 & 0.018 & 0.019 \\
\hline 6 & LN794199_PIAMV_(Concador)_HUN & 0.016 & 0.016 & 0.002 & 0.003 & 0.002 & 0.002 & 0.002 & 0.002 & 0.016 & 0.002 & 0.017 & 0.020 \\
\hline 7 & AY800279_NaMV_(PLH1)_USA & 0.017 & 0.016 & 0.016 & 0.016 & 0.016 & 0.016 & 0.016 & 0.016 & 0.016 & 0.016 & 0.018 & 0.019 \\
\hline 8 & AB360790_PIAMV_(Li1)_JPN & 0.016 & 0.017 & 0.014 & 0.014 & 0.014 & 0.014 & 0.014 & 0.014 & 0.016 & 0.014 & 0.018 & 0.020 \\
\hline 9 & AB360791_PIAMV_(Li2)_JPN & 0.016 & 0.017 & 0.014 & 0.014 & 0.014 & 0.014 & 0.014 & 0.014 & 0.016 & 0.014 & 0.018 & 0.020 \\
\hline 10 & AB360792_PIAMV_(Li3)_JPN & 0.016 & 0.017 & 0.014 & 0.014 & 0.014 & 0.014 & 0.014 & 0.014 & 0.016 & 0.014 & 0.018 & 0.020 \\
\hline 11 & AB360793_PIAMV_(Li4)_JPN & 0.016 & 0.017 & 0.014 & 0.015 & 0.014 & 0.014 & 0.014 & 0.014 & 0.016 & 0.014 & 0.018 & 0.020 \\
\hline 12 & AB360794_PIAMV_(Li5)_JPN & 0.016 & 0.017 & 0.014 & 0.014 & 0.014 & 0.014 & 0.014 & 0.014 & 0.016 & 0.014 & 0.018 & 0.020 \\
\hline 13 & AB360795_PIAMV_(Li6)_JPN & 0.016 & 0.017 & 0.014 & 0.014 & 0.014 & 0.014 & 0.014 & 0.014 & 0.016 & 0.014 & 0.018 & 0.020 \\
\hline 14 & AB360796_PIAMV_(Pr)_JPN & 0.017 & 0.017 & 0.013 & 0.013 & 0.013 & 0.013 & 0.013 & 0.013 & 0.016 & 0.013 & 0.018 & 0.020 \\
\hline 15 & LC155796_PIAMV_(Vi)_JPN & & 0.017 & 0.016 & 0.016 & 0.016 & 0.016 & 0.016 & 0.016 & 0.017 & 0.016 & 0.018 & 0.020 \\
\hline 16 & LC155795_PIAMV_(NJ)_JPN & 0.221 & & 0.016 & 0.016 & 0.016 & 0.016 & 0.016 & 0.016 & 0.016 & 0.016 & 0.018 & 0.020 \\
\hline 17 & KX245539_PIAMV_(CAAS01)_CHN & 0.199 & 0.198 & & 0.003 & 0.002 & 0.002 & 0.002 & 0.002 & 0.016 & 0.002 & 0.017 & 0.020 \\
\hline 18 & KU159093_PIAMV_(Ko-YS)_KOR & 0.201 & 0.198 & 0.005 & & 0.002 & 0.002 & 0.002 & 0.003 & 0.016 & 0.003 & 0.017 & 0.020 \\
\hline 19 & KU159089_PIAMV_(Ko-JJ_2-1)_KOR & 0.201 & 0.198 & 0.002 & 0.003 & & 0.000 & 0.000 & 0.002 & 0.016 & 0.002 & 0.017 & 0.020 \\
\hline 20 & KU159091_PIAMV_(Ko-JJ_2-2)_KOR & 0.201 & 0.198 & 0.002 & 0.003 & 0.000 & & 0.000 & 0.002 & 0.016 & 0.002 & 0.017 & 0.020 \\
\hline 21 & KU159090_PIAMV_(Ko-JJ_2-4)_KOR & 0.201 & 0.198 & 0.002 & 0.003 & 0.000 & 0.000 & & 0.002 & 0.016 & 0.002 & 0.017 & 0.020 \\
\hline 22 & KU159092_PIAMV_(Ko-JJ_3-1)_KOR & 0.203 & 0.199 & 0.003 & 0.005 & 0.002 & 0.002 & 0.002 & & 0.016 & 0.002 & 0.017 & 0.020 \\
\hline 23 & KU697313_PIAMV_(Gunwi)_KOR & 0.213 & 0.181 & 0.162 & 0.162 & 0.162 & 0.162 & 0.162 & 0.162 & & 0.016 & 0.017 & 0.020 \\
\hline 24 & KT717325_PIAMV_(kr)_KOR & 0.203 & 0.198 & 0.003 & 0.005 & 0.002 & 0.002 & 0.002 & 0.003 & 0.162 & & 0.017 & 0.020 \\
\hline 25 & AB066288_TVX_JPN & 0.253 & 0.253 & 0.231 & 0.231 & 0.229 & 0.229 & 0.229 & 0.229 & 0.221 & 0.231 & & 0.020 \\
\hline 26 & NC001812_CymMV_SGP & 0.379 & 0.410 & 0.399 & 0.402 & 0.400 & 0.400 & 0.400 & 0.402 & 0.394 & 0.399 & 0.425 & \\
\hline
\end{tabular}

${ }^{a}$ p-distance values shown below the diagonal (black font) calculated in Mega7 (Kumar et al. 2016) with 5000 permutations and the rate variation among sites was modeled with a gamma distribution (shape parameter $=1$ ). Blue font values above the diagonal are standard error estimates 
Small leaf segments $(1 \times 2 \mathrm{~mm})$ were harvested around chlorotic and necrotic lesions on leaves of one greenhouse lily sample (T188) and were processed for transmission electron microscopy (TEM) as previously described (Montero-Astúa et al. 2017). We detected individual flexuous-rod shaped particles scattered in the cytoplasm (Fig. 1c) similar to those associated with potexviruses (Purcifull et al. 1966). Particle average length was measured from micrographs of tissue sections using ImageJ software (Schneider et al. 2012), selecting only those particles that were clearly visible and not in aggregates. Average particle length was estimated at $516 \mathrm{~nm}$ with a 95\% confidence interval $499-533 \mathrm{~nm}(n=60)$, consistent with PIAMV particle size (490 to $530 \mathrm{~nm}$, Kostin and Volkov 1976, in: Solovyev et al. 1994).

The virus was mechanically inoculated to Nicotiana benthamiana plants and symptoms were observed. Frozen leaf tissue (stored at $-35^{\circ} \mathrm{C}$ ) from each greenhouse lily sample (T188 and T189) was ground in ice-cold $100 \mathrm{mM} \mathrm{Na} 2 \mathrm{SO}_{3}$ using chilled mortars and pestles. The extracts were rubinoculated with carborundum and cotton swabs on two-week old $N$. benthamiana plants (four plants per sample). No symptoms were visible at 15 days after inoculation (dai). A mild mottle was observed at 22 dai (Fig. 1d) and young leaf corrugation and severe chlorotic patterns were observed 36 dai (Fig. 1e) on three and four plants inoculated with T188 and T189 extracts, respectively. One mock inoculated plant (buffer) presented no symptoms (Fig. 1f).

Leaf tissue from the two greenhouse lily samples (T188 and T189) and from the corresponding mechanically inoculated $N$. benthamiana plants tested positive by DAS-ELISA with commercial antibodies against the Nandina mosaic strain of PIAMV (Agdia Inc., Indiana, USA). Moreover, RT-PCR and sequencing (as described previously) from inoculated $N$. benthamiana tissue yielded positive results and sequences corresponding to PIAMV (Table 1). Virus partial sequences obtained from inoculated $N$. benthamiana plants (GenBank accession numbers: KY807783 and KY807785) had the same SNPs as the corresponding source virus sequences (KY807782 and KY807784). Therefore, we confirmed the identity of the virus and its transmission and pathogenicity to $N$. benthamiana. Additionally, we obtained for the first time sequence confirmation (KY807788) for CymMV from Costa
Fig. 2 Phylogenetic tree constructed with Plantago asiatica mosaic virus (PlAMV) sequences, each corresponding to two concatenated fragments of the virus genome, including a partial sequence of the RdRp $\mathrm{ORF}$ and a partial sequence of the coat protein $\mathrm{ORF}$ adding to a final alignment of 689 nucleotide positions with gaps. Each sequence code indicates GenBank accession number, virus species, (isolate, when available) and geographical origin (three letter country code). Sequences were aligned with MUSCLE algorithm in MEGA7 and phylogeny inferred with the maximum likelihood method using a Hasegawa-Kishino-Yano model (HKY) with $\mathrm{G}+\mathrm{I}$ variation rate across sites and 5000 bootstrap replicates. Scale bar represents 0.05 substitutions per site

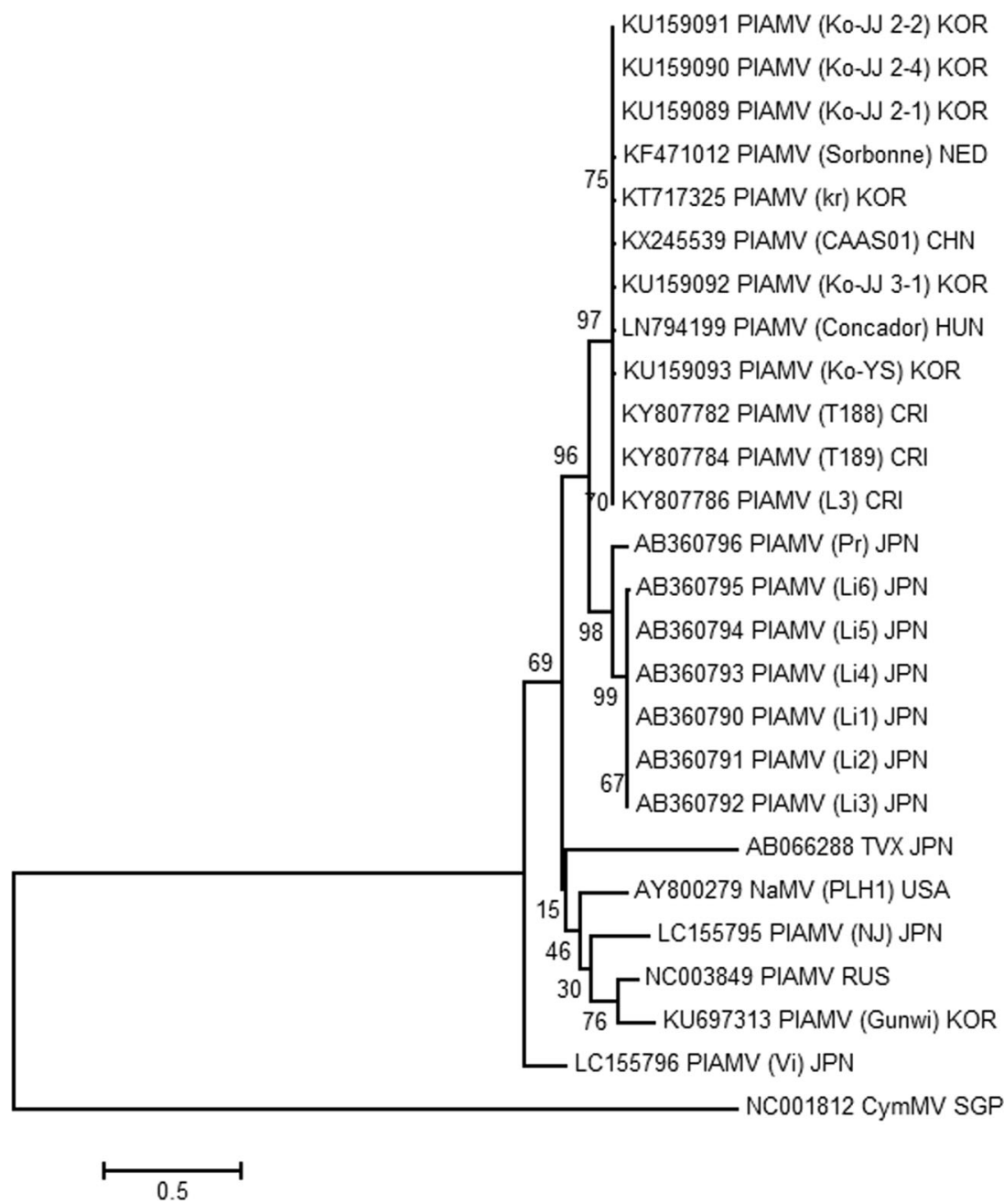


Rica (potexvirus positive control in P. tankervilliae, Moreira et al. 1998). The nucleotide sequences obtained for PlAMV and CymMV are available in GenBank under accession numbers KY807776-KY807788.

The partial sequences obtained with primer pairs Potex 4 / Potex 5 (Miglino et al. 2006) and CP-F2 / CP-R3 (Hammond et al. 2015) for samples T188, T189 and L3 were aligned with corresponding sequences from available PIAMV genomes from GenBank (Table 2) using MUSCLE (Edgar 2004) algorithm in MEGA7 (Kumar et al. 2016). The species Tulip virus $X$ (Yamaji et al. 2001) and Cymbidium mosaic virus (Wong et al. 1997) were included as outgroups. The two sequence alignments: (i) a fragment of the polymerase ORF (33503616, nucleotide positions from Russian reference genome sequence NC003849) and (ii) a fragment of the coat protein ORF (5664-6059) were concatenated with FaBox (Villesen 2007). Phylogenetic analysis was done using a maximum likelihood method with a Hasegawa-Kishino-Yano model (HKY) and a gamma-shaped rate variation across sites with a proportion of invariable sites $(\mathrm{G}+\mathrm{I})$ and 5000 permutations. A Japanese isolate of tulip virus X (TVX) grouped closely with isolates of PIAMV as previously reported (Yamaji et al. 2001). Three putative PIAMV groups were indicated by the dendrogram (Fig. 2). Two clades are supported by a $96 \%$ bootstrap value: one group includes the three lily isolates from Costa Rica, plus isolates from China, Hungary, Korea and The Netherlands; a second clade includes Japanese isolates from lily and one from primrose ( $\mathrm{Pr}$, Primula sieboldii). A third loose group includes isolates from $N$. domestica (USA and Japan) and from P. asiatica (Russia and Korea). Two Japanese isolates, one from $N$. domestica $(\mathrm{NJ})$ and another from Viola grypoceras (Vi) were separated from other Japanese isolates in accordance with a previous report (Komatsu et al. 2017). Komatsu et al. (2008) indicated that the species Plantago asiatica mosaic virus shows high biological and genomic variability. Pairwise nucleotide comparisons (calculated with MEGA7, Table 2) for the concatenate sequence dataset of 24 PlAMV isolates used herein has a mode of 0.141 . The highest distance $(0.221 \pm 0.017)$ was found between two Japanese PIAMV isolates; one from viola (LC155795) and another from nandina (LC155795). Costa Rican isolates were very similar to one another $(0.003 \pm$ 0.002 , or $0.007 \pm 0.003$ ), and showed the highest distance $(0.204 \pm 0.016$, or $0.206 \pm 0.016)$ to the Japanese PlAMV isolate from viola (LC155795), with the lowest distance values $(0.008 \pm 0.004)$ to three Korean lily isolates (KU159089, KU159090, and KU159091).

To our knowledge, this is the first report of PIAMV in Costa Rica. We hypothesize the virus was introduced with imported lily bulbs as has been indicated for other countries (Hammond et al. 2015; Pájtli et al. 2015; Parrella et al. 2015; Vidal et al. 2016; Xu et al. 2017). Symptomless infection of lily was noted in Chile (Vidal et al. 2016) and China (Xu et al.
2017). We also detected a symptomless infection in a commercialized lily plant increasing the risk for unobserved movement and transmission of the disease. These results suggested the need for enhanced virus testing schemes for bulbs and plants to avoid virus dissemination worldwide and emergence of novel diseases due to new virus-host encounters.

Acknowledgments This research was funded by Vicerrectoría de Investigación, Universidad de Costa Rica (801-B3-126) and FundaciónUCR (Project 744).

\section{References}

Adams MJ, Lefkowitz EJ, King AMQ, Harrach B, Harrison RL, Knowles NJ, Kropinski AM, Krupovic M, Kuhn JH, Mushegian AR, Nibert M, Sabanadzovic S, Sanfaçon H, Siddell SG, Simmonds P, Varsani A, Zerbini FM, Gorbalenya AE, Davison AJ (2017) Changes to taxonomy and the international code of virus classification and nomenclature ratified by the international committee on taxonomy of viruses (2017). Arch Virol 162:2505-2538. https://doi.org/10.1007/ s00705-017-3358-5

Anonymous (2010) Plantago asiatica mosaic virus on Lilium spp.: pest report - The Netherlands. Plant protection Service of the Netherlands. https://145.12.37.103/txmpub/files/?p_file_id= 2001424. Accessed 30 Oct 2017

Edgar RC (2004) MUSCLE: a multiple sequence alignment method with reduced time and space complexity. BMC Bioinform 5:113. https:// doi.org/10.1186/1471-2105-5-113

Eiras M, Resende RO, Missiaggia AA, de Ávila AC (2001) RT-PCR and dot blot hybridization methods for a universal detection of tospoviruses. Fitopatol Bras 26:170-175. https://doi.org/10.1590/ S0100-41582001000200009

Hammond J, Bampi D, Reinsel MD (2015) First report of Plantago asiatica mosaic virus in imported Asiatic and oriental lilies (Lilium hybrids) in the United States. Plant Dis 99:292. https://doi.org/10. 1094/PDIS-08-14-0792-PDN

Hughes PL, Harper F, Zimmerman MT, Scott SW (2005) Nandina mosaic virus is an isolate of Plantago asiatica mosaic virus. Eur J Plant Pathol 113:309-313. https://doi.org/10.1007/s10658-005-0624-2

Komatsu K, Yamaji Y, Ozeki J, Hashimoto M, Kagiwada S, Takahashi S, Namba S (2008) Nucleotide sequence analysis of seven Japanese isolates of Plantago asiatica mosaic virus (PlAMV): a unique potexvirus with significantly high genomic and biological variability within the species. Arch Virol 153:193-198. https://doi.org/10. 1007/s00705-007-1078-y

Komatsu K, Yamashita K, Sugawara K, Verbeek M, Fujita N, Hanada K, Uehara-Ichiki T, Fuji S (2017) Complete genome sequence of two highly divergent Japanese isolates of Plantago asiatica mosaic virus. Arch Virol 162:581-584. https://doi.org/10.1007/s00705016-3110-6

Kostin VD, Volkov YG (1976) Some properties of the virus affecting Plantago asiatica L. Virusnye Bolezni Rastenij Dalnego Vostoka 25:205-210. (in Russian)

Kumar S, Stecher G, Tamura K (2016) MEGA7: molecular evolutionary genetics analysis version 7.0 for bigger datasets. Mol Biol Evol 33: 1870-1874. https://doi.org/10.1093/molbev/msw054

Kwon SJ, Cho IS, Yoon JY, Jeong BN (2017) Identification and disease incidence of viruses infecting Chinese foxglove in Korea. Abstract P8-30, Asian Conference on Plant Pathology, Jeju, Korea 
Lim S, Igori D, Zhao F, Do YS, Cho IS, Choi GS, Moon JS (2016) Molecular detection and characterization of a divergent isolate of Plantago Asiatica mosaic virus in Plantago asiatica. Virus Dis 27: 307-310. https://doi.org/10.1007/s13337-016-0329-5

Miglino R, Jodlowska A, van Schadewijk AR (2006) Detection and identification of a novel Potexvirus infecting allium by paramagnetic beads ssRNA isolation and one tube RT-PCR assay with a new Potexvirus genus primer set. Acta Hortic (722):285-292. 10. 17660/ActaHortic.2006.722.35

Montero-Astúa M, Dejuk-Protti N, Vásquez E, Garita L, Moreira L (2017) First report of Iris yellow spot virus in Costa Rica. Australas Plant Dis Notes 12:18. https://doi.org/10.1007/s13314017-0243-8

Moreira L, Villalobos W, Hsu HT, Rodríguez-Cerezo E, Rivera C (1998) First report of Cymbidium mosaic potexvirus (CymMV) infecting the terrestrial orchid Phaius tankervilliae in Costa Rica. Plant Dis 82:1171. https://doi.org/10.1094/PDIS.1998.82.10.1171D

Ozeki J, Takahashi S, Komatsu K, Kagiwada S, Yamashita K, Mori T, Hirata H, Yamaji Y, Ugaki M, Namba S (2006) A single amino acid in the RNA-dependent RNA polymerase of Plantago asiatica mosaic virus contributes to systemic necrosis. Arch Virol 151:20672075. https://doi.org/10.1007/s00705-006-0766-3

Pájtli É, Eke S, Palkovics L (2015) First report of the Plantago asiatica mosaic virus (PlAMV) incidence on Lilium sp. in Hungary. Plant Dis 99:1288. https://doi.org/10.1094/PDIS-01-15-0107-PDN

Parrella G, Greco B, Pasqualini A, Nappo G (2015) Plantago asiatica mosaic virus found in protected crops of lily hybrids in Southern Italy. Plant Dis 99:1289. https://doi.org/10.1094/PDIS-03-15-0281-PDN

Purcifull DE, Edwardson JR, Christie RG (1966) Electron microscopy of intracellular aggregates in pea (Pisum sativum) infected with clover yellow mosaic virus. Virology 29:276-284. https://doi.org/10.1016/ 0042-6822(66)90034-1
Schneider CA, Rasband WS, Eliceiri KW (2012) NIH image to ImageJ: 25 years of image analysis. Nat Methods 9:671-675. https://doi.org/ 10.1038/nmeth.2089

Solovyev AG, Novikov VK, Merits A, Savenko EI, Zelenina DA, Tyulkina LG, Morozov SY (1994) Genome characterization and taxonomy of Plantago asiatica mosaic potexvirus. J Gen Virol 75: 259-267. https://doi.org/10.1099/0022-1317-75-2-259

Uga H, Tsuda S (2005) A one-step reverse transcription-polymerase chain reaction system for the simultaneous detection and identification of multiple tospovirus infections. Phytopathology 95:166-171. https:// doi.org/10.1094/PHYTO-95-0166

Vidal AK, Camps R, Besoain X (2016) First report of necrotic streaking of Asiatic lilies caused by Plantago asiatica mosaic virus in Chile. Plant Dis 100:1799. https://doi.org/10.1094/PDIS-01-16-0091-PDN

Villesen P (2007) FaBox: an online toolbox for fasta sequences. Mol Ecol Notes 7:965-968. https://doi.org/10.1111/j.1471-8286. 2007.01821.x

Wong SM, Mahtani PH, Lee KC, HH Y, Tan Y, Neo KK, Chan Y, Wu M, Chng CG (1997) Cymbidium mosaic potexvirus RNA: complete nucleotide sequence and phylogenetic analysis. Arch Virol 142: 383-391. https://doi.org/10.1007/s007050050084.pdf

Xu LF, Ming J, Yuan SX (2017) First report of Plantago asiatica mosaic virus in lily hybrids in China. Plant Dis 101:263. https://doi.org/10. 1094/PDIS-06-16-0819-PDN

Yamaji Y, Kagiwada S, Nakabayashi H, Ugaki M, Namba S (2001) Complete nucleotide sequence of Tulip virus $X$ (TVX-J): the border between species and strains within the genus Potexvirus. Arch Virol 146:2309-2320. https://doi.org/10.1007/s007050170004.pdf

Zettler FW, Hiebert E, Maciel-Zambolim E, Christie RG, El-Nil MMA (1980) A potexvirus infecting Nandina domestica 'Harbor Dwarf'. Acta Hortic (110):71-77. 10.17660/ActaHortic.1980.110.7 